\title{
RETRACTED
}

\section{Socio-Cultural Aspect in Ludruk Tragedi Kebun Tebu: Strengthening National Character Education}

\author{
Herlina Kusuma Wardani ${ }^{1}$, Andayani ${ }^{2}$, Djoko Sulaksono ${ }^{3}$, and Kundharu Saddhono ${ }^{4}$ \\ \{wardani.herlinakusuma@student.uns.ac.id ${ }^{1}$, bu_anda09@yahoo.co.id ${ }^{2}, \&$ \\ ciptaningmintaraga@yahoo.com ${ }^{3}$, kundharu_s@staff.uns.ac.id ${ }^{4}$ \} \\ 1,2,3,4 Universitas Sebelas Maret, Surakarta, Indonesia
}

\begin{abstract}
This study aims to describe socio-cultural aspects in ludruk titled Tragedi Kebun Tebu and the ludruk's effectin strengthening national character implementation in Senior High School. The ludruk Tragedi Kebun Tebu written by Cak Edy Karya, told a story about Sukarsih and Sukandar that were able to face all the hardships during their lives and also taken part during the struggle of defending the homeland (Indonesia). This research is a qualitative descriptive study with a socio-cultural aspect content analysis approach. Data collected using interview, observation and documentation. To test data validity, the writer use source and method triangulation. Socio-cultural aspects in the story consisting of religion, tribe, customs and beliefs, jobs, languages and residence. The ludruk helps strengthening national character implementation in terms of: First, Basic Competence of XII grade in 2013 curriculum in East Java, point 3.3. Identifiying, understanding and analyzing performing arts and point 4.5. Do performing arts (poetry musicalization, dramatization of literary works, comedy, music and songs, and fairy tales). Seconds, key national character values are the spirit of nationality and love of homeland.
\end{abstract}

Keywords: ludruk, socio-cultural, character education

\section{INTRODUCTION}

Ludruk is a traditional theater that is unique and owned by people in the East Java province. Ludruk's performance was done improvised with a short text from an author. The language used is Javanese. Javanese is one of the regional languages in Indonesia that has a very large number of speakers, resulting in variations in language / dialect [1]. The use of language in ludruk staging is not a standard [2]. The convention / standard in the performance of ludruk is the accompaniment of the gamelan, opened with the Ngremo dance, kidungan, then the story / play. The ludruk performance was also presented so that the message to be conveyed was not offensive to one of the parties.

Several studies on ludruk from language aspect have been carried out. One of them is the pragmatic approach. The study of the play of ludruk Joko Sambang Pendekar Gunung Gangsir found four categories of illocutionary speech acts used by players [3]. Ludruk's research from the aspect of literature, one of which, is the feminism approach. Research on Susi Duyung's play 